\title{
Phosphorus dietary assimilation and efflux in the marine copepod Acartia erythraea
}

\author{
Sheng Liu ${ }^{1,2}$, Wen-Xiong Wang ${ }^{1, *}$, Liang-Min Huang ${ }^{2}$ \\ ${ }^{1}$ Department of Biology, The Hong Kong University of Science and Technology (HKUST), Clear Water Bay, Kowloon, \\ Hong Kong, SAR \\ ${ }^{2}$ LAMB, South China Sea Institute of Oceanology, Chinese Academy of Sciences, Xingang West Road 164, \\ Guangzhou 510301, PR China
}

\begin{abstract}
We examined the metabolism of phosphorus (P), including its dietary assimilation, efflux, and regeneration, in the marine subtropical copepod Acartia erythraea feeding on diverse types of marine phytoplankton. The P assimilation efficiency (AE) ranged between 19 and $78 \%$ when the copepods were fed 6 algal diets at the same concentration $\left(1.45 \mathrm{mg} \mathrm{C}^{-1}\right)$. Among the different algal diets, the AEs were not significantly related to the ingestion rate and the food gut passage time of copepods, or the P partitioning in the algal cytoplasm. The P AE decreased ca. 2-fold when the food concentration increased from 0.073 to $3.625 \mathrm{mg} \mathrm{C}^{-1}$, but was not influenced by the $\mathrm{P}$ quota in diatoms. The $\mathrm{P}$ efflux rates in the copepods feeding on diatoms were 0.30 to $0.36 \mathrm{~d}^{-1}$ over the food concentrations examined; the efflux rate was significantly higher when the copepods ingested diatoms with higher $\mathrm{P}$ quotas, suggesting that the $\mathrm{P}$ homeostasis in the copepods may possibly be achieved by efflux of P from the body. During the dietary assimilation and efflux periods, most P lost from the copepods was regenerated into the dissolved phase and only a small portion of $\mathrm{P}$ was detected in other compartments (mainly in the feces), suggesting that copepods rapidly regenerate particulate $\mathrm{P}$ into the surrounding waters. Our study indicated that both P dietary assimilation and efflux can play an important role in maintaining the P stoichiometry in copepods.
\end{abstract}

KEY WORDS: Phosphorus $\cdot{ }^{33} \mathrm{P} \cdot$ Copepods $\cdot$ Assimilation $\cdot$ Efflux $\cdot$ South China Sea

\section{INTRODUCTION}

Phosphorus (P), as a component of enzymes, ATP, and nucleic acids, is an essential nutrient for structural and functional health in organisms. In aquatic environments, $\mathrm{P}$ is presented in various physico-chemical forms (e.g. as orthophosphate, pyrophosphate, polyphosphate) (House 2003). Compared with other potentially biolimiting elements, the marine biological productivity is believed to be controlled by the bioavailability of dissolved P on a geological time scale (Redfield 1958, Tyrrell 1999, Klausmeier et al. 2004). The biogeochemical cycles of $\mathrm{P}$ in aquatic ecosystems have thus gained wide attention (Tyrell 1999, House 2003, Klausmeier et al. 2004). The speciation, distribution, and cycling of $\mathrm{P}$ in aquatic environments have been extensively studied (House 2003, Zhang et al.
2004). Many studies demonstrated that although the amounts of macronutrients increase in coastal waters due to obvious anthropogenic activities, $\mathrm{P}$ is a potentially limiting nutrient to primary productivity, e.g. in Hong Kong's coastal waters (Zhang et al. 1999, Yin et al. 2000, Miao et al. 2006).

In aquatic ecosystems, zooplankton play a key role in the transfer of materials and energy along the food chain. They may influence the biogeochemical cycles of nutrients by actively feeding on phytoplankton and by regeneration of nutrients (Hargrave \& Geen 1968, Reinfelder \& Fisher 1991, Hutchins et al. 1995, Wang \& Fisher 1998). Zooplankton can be both a sink and a source of an element, depending on the environmental conditions (Hargrave \& Geen 1968, Andersen \& Hessen 1991). Recent studies indicated that regenerated $P$ is an important source for supporting biological pro- 
ductivity (Paytan et al. 2003), especially in areas of high primary production with low $\mathrm{P}$ concentration (Zhang et al. 2004). Zooplankton regeneration may supply over half of the $\mathrm{P}$ requirements for phytoplankton growth (Perry \& Eppley 1981), and it may even meet all the phytoplankton P requirements (James \& Salonen 1991). The elemental composition of copepods is relatively constant. Andersen \& Hessen (1991) reported that many marine copepods had low $\mathrm{P}$ contents and high N/P ratios, e.g. their $\mathrm{P}$ contents were almost equal to $0.76 \pm 0.18 \%$ of their body weights. Walve \& Larsson (1999) demonstrated that the $\mathrm{P}$ content of Acartia sp. fluctuated between 1 and $2 \%$ of their body weight in different growth stages and seasons in the Baltic Sea. These results indicate that copepods might assimilate P from food at a relatively stable ratio (Hessen 1990). However, mechanisms for maintaining the $P$ stoichiometry in marine copepods remain largely unexplored at present, in contrast to ample studies in freshwater zooplankton (Sterner \& Elser 2002).

$\mathrm{P}$ assimilation and excretion by zooplankton are key processes in the overall $\mathrm{P}$ cycling in aquatic environments. These processes may be affected by many factors such as food characteristics (P content and distribution in the food) and the feeding kinetics of animals. Marshall \& Orr (1961) first reported that copepods could not completely assimilate ingested $\mathrm{P}$ and that ca. 10 to $50 \%$ of ingested P ended in their fecal pellets. Bulter et al. (1970) observed that Calanus finmarchicus assimilated only $17 \%$ of $\mathrm{P}$ from food, while $23 \%$ of ingested $\mathrm{P}$ was released as feces and $60 \%$ was directly excreted as dissolved inorganic P into the water. This early study implied the importance of $\mathrm{P}$ regeneration into the dissolved phase (as excreted products), because of the relatively low dietary assimilation. Reinfelder \& Fisher (1991) found that copepods assimilated the elements only from the cytoplasm of algae because of the short gut residence time of food materials. The assimilation efficiency (AE) of P was ca. 72\% in Acartia tonsa (Reinfelder \& Fisher 1991). Other studies showed that $\mathrm{P}$ AE in Calanus sp. fluctuated between 40 and $77 \%$ (Corner et al. 1972). Despite these much earlier studies, there is still missing information in regard to the biogeochemical fate of $\mathrm{P}$ in aquatic environments, especially regarding the biologically mediated regeneration by copepod grazing. For example, the $\mathrm{P}$ efflux rate for marine copepods is unknown, but this rate is essential in clarifying the interdependence between $\mathrm{P}$ cycling and ecosystem response, as well as in predicting the stoichiometry of $\mathrm{P}$ in copepods.

Acartia erythraea is a neritic copepod species, abundant in the coastal waters of the South China Sea during late summer and autumn. In the present study, we measured the dietary assimilation, release, and physiological turnover rates of $\mathrm{P}$ in $A$. erythraea under different conditions, including different phytoplankton species and abundances, as well as different P quotas in their food particles. We examined the relationships between dietary $\mathrm{P}$ assimilation and the feeding activity (food gut passage time, ingestion rate) of copepods. Our results may provide a basis for predicting the homeostasis of $\mathrm{P}$ in marine copepods when they respond to different environmental conditions and for understanding $\mathrm{P}$ cycling as mediated by zooplankton grazing in marine waters.

\section{MATERIALS AND METHODS}

Adult copepods Acartia erythraea were collected by plankton net (250 $\mu \mathrm{m}$ mesh size) towing in Port Shelter, Clear Water Bay, Hong Kong. A. erythraea is the dominant zooplankton species in the subtropical coastal waters of the South China Sea in the summer and autumn. Typical dry weights of adults were $5.2 \pm 0.2 \mu \mathrm{g}$ ind. ${ }^{-1}$, with a $\mathrm{C}, \mathrm{N}$, and $\mathrm{P}$ content of $3.03 \pm 0.26,1.02 \pm$ 0.10 , and $0.035 \pm 0.000 \mu \mathrm{g}$ ind.$^{-1}$, respectively. The copepods were maintained in the laboratory in glassfiber-filtered (GFF) seawater (32 $\pm 1 \%$ ) and fed a diet of mixed algae (diatoms Thalassiosira weissflogii and Thalassiosira pseudonana, dinoflagellate Prorocentrum minimum, and prasinophyte Tetraselmis levis) for 1 to $2 \mathrm{~d}$ prior to the experiments described below. The radioisotope ${ }^{33} \mathrm{P}$ (from New England Nuclear) was used to trace $\mathrm{P}$ behavior throughout the course of the experiments.

A total of 6 species of algae were tested in this study: Thalassiosira weissflogii (CCMP 1048), Thalassiosira pseudonana (CCMP 1335), Phaeodactylum tricornutum (CCMP 630), Tetraselmis levis (CCMP 896), Prorocentrum minimum (CCMP 696), and Dunaliella tertiolecta (CCMP 1320). These algae were purchased from the Provasoli-Guillard Phytoplankton Collection Center, Maine, USA, and maintained in $f / 2$ medium (19 or $23^{\circ} \mathrm{C}$ ) under an illumination of $100 \mu \mathrm{mol}$ photons $\mathrm{m}^{-2} \mathrm{~s}^{-1}$, with a 14:10 h light:dark cycle. To radiolabel the phytoplankton, the late-log-phase cells were gently filtered onto 1 or $3 \mu \mathrm{m}$ polycarbonate membranes at vacuum pressure $<50 \mathrm{~mm} \mathrm{Hg}$ and resuspended in $0.2 \mu \mathrm{m}$ filtered seawater at an initial cell concentration of 1 to $2 \times 10^{4}$ cells $\mathrm{ml}^{-1}$ (depending on different algal species). The algal carbon content was measured using a CHN element analyzer (Leco CHN-900) at $650^{\circ} \mathrm{C}$. The radioisotope addition was $0.5 \mu \mathrm{Ci} \mathrm{ml}{ }^{-1}$ for ${ }^{33} \mathrm{P}$. After 3 to $5 \mathrm{~d}$ of growth, the cells grew $>3$ generations and were considered to be uniformly labeled. They were collected again and rinsed with $0.2 \mu \mathrm{m}$ filtered seawater to remove the weakly bound P on the cell surfaces. 
Phosphorus assimilated by copepods. Three independent experiments were conducted to determine the P AE by the copepods fed with different species, a different $\mathrm{P}$ status of algae, or at different algal densities. In experiments with different species of algae, a total of 6 species were chosen (Thalassiosira weissflogii, Thalassiosira pseudonana, Phaeodactylum tricornutum, Tetraselmis levis, Prorocentrum minimum, and Dunaliella tertiolecta). The biomass was the same for

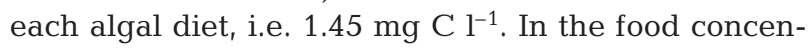
tration experiments, only $T$. weissflogii was used, and the cell densities were $0.073,0.363,0.725,1.450$, and $3.625 \mathrm{mg} \mathrm{Cl}^{-1}$. In the third experiment, we tested the influences of different cellular quotas of $\mathrm{P}$ in the diatoms on the P AE by the copepods. The diatoms $T$. weissflogii were grown under different $\mathrm{P}$ concentrations $(0.72,7.2$, and $36.2 \mu \mathrm{M}$ P). Other macronutrients were at $f / 2$ levels. Each day, the cells were gently collected with a $3 \mu \mathrm{m}$ membrane and resuspended into $0.2 \mu \mathrm{m}$ seawater containing the new medium. After 2 wk of semi-continuous culture, the cells were harvested for the feeding experiments (at a cell density of $1.45 \mathrm{mg} \mathrm{C}^{-1}$ ).

All experiments were conducted at room temperature $\left(23^{\circ} \mathrm{C}\right)$. The copepods first evacuated their gut contents into filtered seawater without food for $1 \mathrm{~h}$ and then were transferred to $100 \mathrm{ml}$ filtered seawater at a density of 0.6 ind. $\mathrm{ml}^{-1}$. Each food treatment had 3 replicated beakers. The radiolabeled algae were then added to the feeding beakers, and the total feeding time was 15 min under dark conditions. The short radioactive feeding period avoided the production of radioactive fecal pellets. The total amount of ${ }^{33} \mathrm{P}$ ingested by copepods could be quantified accurately. The copepods were collected with $250 \mu$ m nylon mesh after radioactive feeding and rinsed with filtered seawater. Two individuals were immediately removed for beta-counting, as described below. The remaining individuals were quickly returned to filtered seawater containing unradiolabeled food at the same carbon biomass. Copepods were depurated for $12 \mathrm{~h}$ under such conditions, during which time 10 individuals were removed at 1 to $4 \mathrm{~h}$ intervals for radioactivity counting. Similarly, any feces and $10 \mathrm{ml}$ water were simultaneously collected for ${ }^{33} \mathrm{P}$ measurements at each time point during the depuration period. After each sampling, seawater and food were renewed.

Assimilation efficiency (AE) is defined as the fraction that is incorporated into the body tissues after the digestive products are taken up and absorbed across the cell membrane of the gut wall. Since the time required for a complete absorption and assimilation of elements is longer than the gut passage time of ingested food materials (Wang \& Fisher 1996), it is impractical to calculate the AE based on the gut pas- sage time of ingested food $(<1 \mathrm{~h})$. In our study, there was still appreciable depuration of ingested ${ }^{33} \mathrm{P}$ from the copepods during 2 to $12 \mathrm{~h}$ of depuration (see data below); the AE was thus operationally calculated as the $\%$ of ingested $\mathrm{P}$ remaining in the slower exchanging compartment (between 2 and $12 \mathrm{~h}$ ), which was the $y$-intercept of the linear regression between the natural log of the \% of P retained and the time of depuration (Wang \& Fisher 1999).

Phosphorus efflux by copepods. We tested the influences of algal cell density and cellular P quotas on the efflux of ingested $P$ by copepods. The efflux rates were quantified after the copepods were fed with the radiolabeled diatoms for a long period of time $(2 \mathrm{~d})$, enabling the radiolabeled $\mathrm{P}$ to be uniformly distributed in the copepods. The diatoms Thalassiosira weissflogii were used in these experiments. In the first experiment, the diatoms were radiolabeled with ${ }^{33} \mathrm{P}$ for $3 \mathrm{~d}_{i}$ they were collected on a $3 \mu \mathrm{m}$ membrane and resuspended in filtered seawater to give cell densities of $0.073,0.363,0.725,1.450$, and $3.625 \mathrm{mg} \mathrm{C} \mathrm{l}^{-1}$. There were 3 replicates for each food concentration treatment. The copepods were fed with radiolabeled food for $2 \mathrm{~d}$. Every 4 to $6 \mathrm{~h}$, the radiolabeled diatoms were added to maintain a relatively constant food concentration in the feeding beakers. After feeding on the radioactive food for $2 \mathrm{~d}$, the copepods were collected with $250 \mu \mathrm{m}$ mesh, rinsed with filtered seawater, and their guts were allowed to evacuate for $1 \mathrm{~h}$. The copepods were then transferred to $150 \mathrm{ml}$ water at a density of 0.8 ind. $\mathrm{ml}^{-1}$ (120 individuals in total, with 10 individuals removed for measurements every 2 to $8 \mathrm{~h}$ ), and the food concentrations were the same as those used during the radioactive feeding period. During the $64 \mathrm{~h}$ depuration period, 10 individual copepods and feces were collected every 2 to $8 \mathrm{~h}$ and rinsed with filtered seawater. Another $5 \mathrm{ml}$ of water was sampled to measure the $\mathrm{P}$ distribution in different compartments (water and feces). After each sampling, the seawater and food were renewed.

In the second experiment, the diatom Thalassiosira weissflogii was grown at different $\mathrm{P}$ concentrations $(0.7,7.2$, and $36.2 \mu \mathrm{M})$, whereas the concentrations of other macronutrients were maintained at $f / 2$ levels. Each day, the cells were gently collected and resuspended into filtered seawater containing the new medium. After 2 wk of semi-continuous culture, the cells were harvested and fed to the copepods at a cell density of $1.45 \mathrm{mg} \mathrm{C}^{-1}$ for $2 \mathrm{~d}$. The efflux of P by the copepods was then quantified using the approaches described above.

Ingestion rate (IR) and food gut passage time (FPT). The IR of copepods grazing on different algae was quantified at an algal density of $1.45 \mathrm{mg} \mathrm{C}^{-1}$. The copepod density in the experiment beakers was 


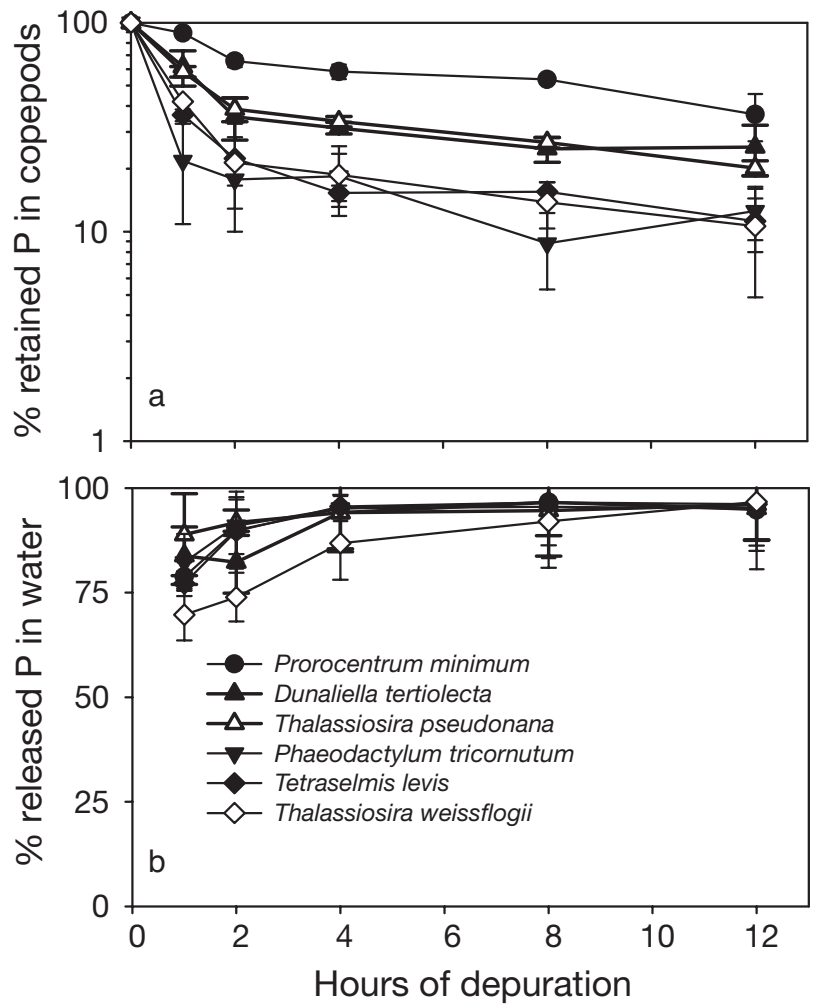

Fig. 1. Acartia erythraea. (a) Retention of dietary ${ }^{33} \mathrm{P}$ in copepods and (b) the relative distribution of eliminated $\mathrm{P}$ in the water following a 15 min pulse ingestion of different radiolabeled phytoplankton. Cell biomass was maintained at $1.45 \mathrm{mg} \mathrm{C} \mathrm{l}^{-1}$ for the different algal species. Data are means $( \pm \mathrm{SD}, \mathrm{n}=3)$

0.2 ind. $\mathrm{ml}^{-1}$. A control treatment containing algae only was used to monitor algal growth during the incubation period $(6 \mathrm{~h})$. All the experiment beakers were then placed on a Ferris cell (rotating wheel) under dark conditions at a speed of $2 \mathrm{rpm}$. Each experimental treatment had 3 replicates. The initial and final cell densities were measured using a Coulter Counter. The IR was finally calculated according to the equation described by Omori \& Ikeda (1992). In addition, we also quantified the FPT. Before the experiments, the copepods were kept in filtered seawater to evacuate their guts for $1 \mathrm{~h}$. Algal suspension $(10 \mathrm{ml})$ was then transferred to a deep-well dish containing 1 individual copepod. Every 3 to $5 \mathrm{~min}$ over a period of $3 \mathrm{~h}$, the copepod was checked under a light microscope to examine whether any feces were produced. The experiment was terminated when the first feces appeared (defined as the FPT). There were 8 individual copepods (replicates) in this experiment.

Recycling of regenerated phosphorus by copepods and algae. This experiment tested the recycling of $\mathrm{P}$ regenerated by the copepods in our experimental systems. About 500 individual copepods were used in this experiment. After feeding on the radiolabeled algae
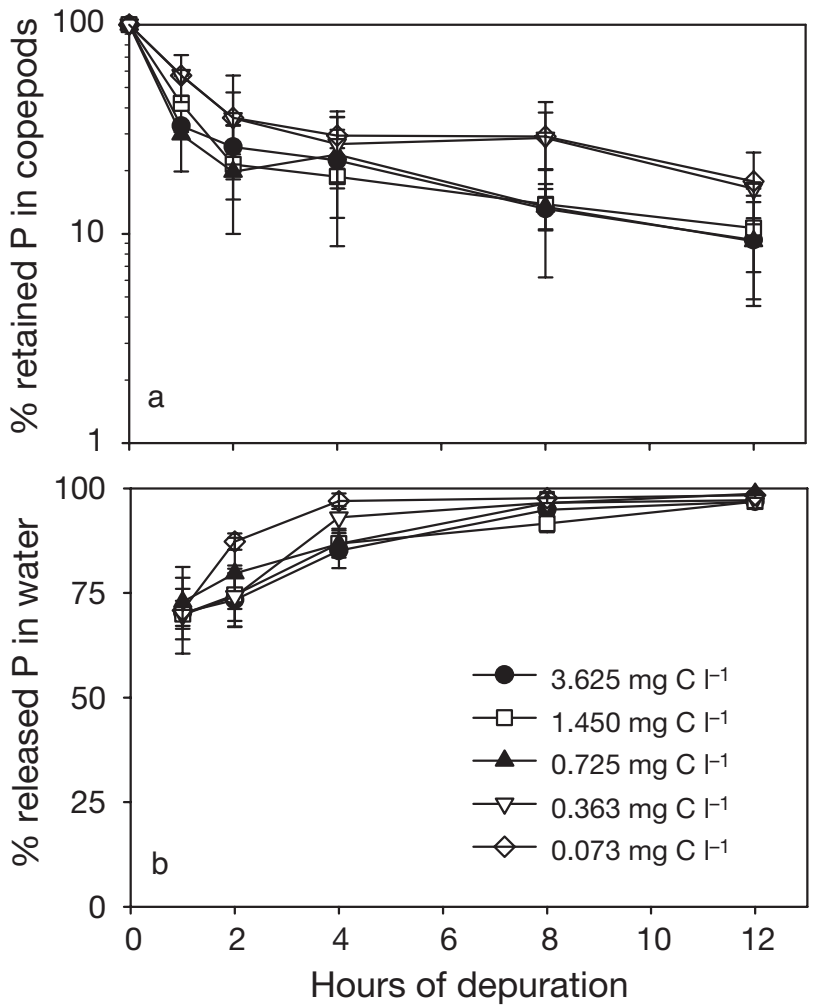

Fig. 2. Acartia erythraea. (a) Retention of dietary ${ }^{33} \mathrm{P}$ in copepods and (b) the relative distribution of eliminated $\mathrm{P}$ in the water following a $15 \mathrm{~min}$ pulse ingestion of the radiolabeled diatoms Thalassiosira weissflogii at different concentrations. Data are means $( \pm \mathrm{SD}, \mathrm{n}=3)$

for $>12 \mathrm{~h}$, the copepods were collected using the $40 \mu \mathrm{m}$ mesh, transferred to filtered seawater immediately, and depurated for $12 \mathrm{~h}$, during which time the copepods and feces released $\mathrm{P}$ into the seawater. The copepods and feces were then removed, and the seawater containing the regenerated $\mathrm{P}$ was used in the recycling experiments. In one treatment, the copepods were added without the presence of food materials to directly quantify the accumulation of regenerated $\mathrm{P}$ by the copepods (at a copepod density of 0.6 ind. $\mathrm{ml}^{-1}$ ). In another treatment, the copepods were added in the presence of the diatoms Thalassiosira weissflogii at different cell densities $\left(0.073,1.450\right.$, and $\left.3.625 \mathrm{mg} \mathrm{C} \mathrm{l}^{-1}\right)$ to quantify the accumulation of $\mathrm{P}$ in the copepods (which included the absorption of regenerated $\mathrm{P}$ by the diatoms followed by copepod grazing). The diatoms were previously inoculated under different $\mathrm{P}$ concentrations as described above (i.e. 36.2, 7.2 $\mu \mathrm{M}$, and $\mathrm{P}$ starvation). Each treatment had 3 replicate bottles. At 2,4 , and $6 \mathrm{~h}$, the copepods were collected and their uptake of regenerated $\mathrm{P}$ was measured by quantifying the ${ }^{33} \mathrm{P}$ radioactivity in them.

Radioactivity measurements and statistical analysis. Before counting ${ }^{33} \mathrm{P}$ radioactivity, the samples were 


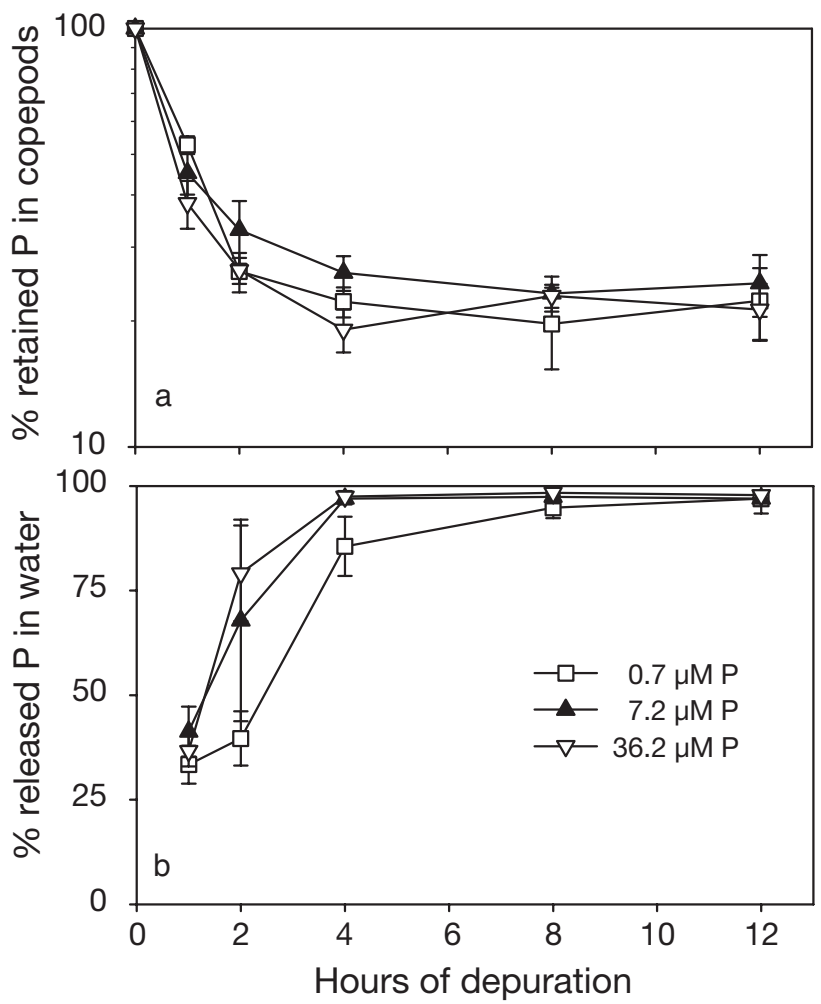

Fig. 3. Acartia erythraea. (a) Retention of dietary ${ }^{33} \mathrm{P}$ in copepods and (b) the relative distribution of eliminated $\mathrm{P}$ in the water following a $15 \mathrm{~min}$ pulse ingestion of the radiolabeled diatoms Thalassiosira weissflogii inoculated at different $\mathrm{P}$ concentrations. Data are means $( \pm \mathrm{SD}, \mathrm{n}=3)$

mixed with cocktails at a sample to cocktail ratio of 1:4 and were placed in darkness for at least $12 \mathrm{~h}$. The copepod samples were first dissolved in $0.5 \mathrm{~N} \mathrm{NaOH}$ at $80^{\circ} \mathrm{C}$ for $8 \mathrm{~h}$ before the addition of cocktails. The radioactivity of ${ }^{33} \mathrm{P}$ was determined using a Wallac WinSpectral 1414 liquid scintillation counter. Statistical analysis was performed using 1-way ANOVA, following appropriate arcsine transformation of the percentage data. Tukey's HSD (honestly significant difference) multiple comparison tests were used to detect the differences between groups. Differences were considered significant at $\mathrm{p}<0.05$.

\section{RESULTS}

\section{Phosphorus assimilation}

P was rapidly released by the copepods Acartia erythraea within the first $2 \mathrm{~h}$ following a pulse ingestion of radiolabeled phytoplankton (Figs. 1 to 3). Since there was still appreciable depuration of ingested ${ }^{33} \mathrm{P}$ from the copepods during a 2 to $12 \mathrm{~h}$ period, the AE was operationally calculated as the percentage of $\mathrm{P}$ remaining in the more slowly exchanging compartment (between 2 and $12 \mathrm{~h}$ ), using methods described in Wang \& Fisher (1999). The AE varied among different phytoplankton diets at the same food concentration (1.45 $\mathrm{mg} \mathrm{C}^{-1}$ ), ranging between 19 and $78 \%$ (Table 1). The highest AE was observed for the dinoflagellate Prorocentrum minimum, and the AEs were comparable for Thalassiosira weissflogii, Phaeodactylum tricornutum, and Tetraselmis levis. In this experiment, the percentage of released $\mathrm{P}$ partitioning in the dissolved phase $(<0.2 \mu \mathrm{m})$ was also quantified during the depuration period. The majority of released $\mathrm{P}$ was found in the dissolved phase, whereas only a very small percentage of $\mathrm{P}$ was detected in the particles (mainly as feces), suggesting that copepods rapidly regenerated the $\mathrm{P}$ into the surrounding waters. Furthermore, the fraction of $\mathrm{P}$ in the dissolved phase increased with increasing depuration time.

In experiments with different concentrations of Thalassiosira weissflogii, the $\mathrm{P}$ retention was comparable among the 3 high food concentrations $(0.725,1.450$ and $3.625 \mathrm{mg} \mathrm{C} \mathrm{l}^{-1}$ ) and between the 2 low food concentrations (0.073 and $0.363 \mathrm{mg} \mathrm{C}^{-1}$ ) (Fig. 2). At a food concentration $<0.363 \mathrm{mg} \mathrm{C}^{-1}$, the $\mathrm{P}$ retention in the copepods after $12 \mathrm{~h}$ of depuration was $>16 \%$, but decreased to ca. $10 \%$ when the diatom density was $>0.725 \mathrm{mg} \mathrm{C}$ $\mathrm{l}^{-1}$. The calculated AEs decreased ca. 2-fold when the

Table 1. Acartia erythraea. Phosphorous algal content and distribution in the algal cytoplasm, food gut passage time (FPT), ingestion rate (IR), and $\mathrm{P}$ assimilation efficiency (AE) in the copepods feeding on different phytoplankton at the same cell biomass $\left(1.45 \mathrm{mg} \mathrm{C}^{-1}\right)$. Data are means $( \pm \mathrm{SD}, \mathrm{n}=3$ for percent in cytoplasm, IR, and $\mathrm{AE}$, and $\mathrm{n}=8$ for FPT). Superscripts bearing the same letters in each column mean that no significant difference between the 2 algal diets was found

\begin{tabular}{|lcccccc|}
\hline Algal diet & $\begin{array}{c}\text { Cell size } \\
(\mu \mathrm{m})\end{array}$ & $\begin{array}{c}\text { P content } \\
(\%)\end{array}$ & $\begin{array}{c}\text { Percent in } \\
\text { cytoplasm }\end{array}$ & $\begin{array}{c}\text { FPT } \\
\left(\mathrm{min}^{\mathrm{m}}\right)\end{array}$ & $\begin{array}{c}\text { IR }(\mu \mathrm{g} \mathrm{C} \\
\left.\operatorname{copepod}^{-1} \mathrm{~h}^{-1}\right)\end{array}$ & $\begin{array}{c}\mathrm{AE} \\
(\%)\end{array}$ \\
\hline Thalassiosira weissflogii & $8-10 \times 14-18$ & 0.51 & $71.0 \pm 2.3^{\mathrm{a}}$ & $38 \pm 3^{\mathrm{a}}$ & $0.34 \pm 0.08^{\mathrm{a}}$ & $23.2 \pm 0.8^{\mathrm{a}}$ \\
Thalassiosira pseudonana & $4-5 \times 4-6$ & 0.75 & $64.1 \pm 6.6^{\mathrm{a}, \mathrm{b}}$ & $43 \pm 6^{\mathrm{a}, \mathrm{b}}$ & $0.24 \pm 0.03^{\mathrm{a}}$ & $41.7 \pm 2.5^{\mathrm{b}}$ \\
Phaeodactylum tricornutum & $4-5 \times 24-29$ & 0.37 & $61.7 \pm 1.1^{\mathrm{b}}$ & $48 \pm 3^{\mathrm{b}}$ & $0.21 \pm 0.05^{\mathrm{a}}$ & $19.3 \pm 2.7^{\mathrm{c}}$ \\
Tetraselmis levis & $6-10 \times 10-12$ & 1.11 & $52.9 \pm 0.2^{\mathrm{c}}$ & $43 \pm 3^{\mathrm{a}, \mathrm{b}}$ & $0.80 \pm 0.02^{\mathrm{b}}$ & $23.8 \pm 4.7^{\mathrm{a}, \mathrm{c}}$ \\
Prorocentrum minimum & $10-12 \times 13-16$ & 0.70 & $85.5 \pm 3.4^{\mathrm{d}}$ & $37 \pm 3^{\mathrm{a}}$ & $1.33 \pm 0.22^{\mathrm{c}}$ & $78.1 \pm 4.2^{\mathrm{d}}$ \\
Dunaliella tertiolecta & $1-3 \times 6-9$ & 1.10 & $83.1 \pm 4.6^{\mathrm{d}}$ & $57 \pm 3^{\mathrm{c}}$ & $0.73 \pm 0.22^{\mathrm{b}}$ & $33.8 \pm 3.0^{\mathrm{e}}$ \\
\hline
\end{tabular}


food concentration increased from 0.363 to $0.725 \mathrm{mg} \mathrm{C}$ $\mathrm{l}^{-1}$ (Table 2). Similarly, the majority of depurated P was found in the dissolved phase, and there was no trend in the relative partitioning of depurated $\mathrm{P}$ among different food concentration treatments (Fig. 2).

The IR of Acartia erythraea was highly dependent on the food species and increased with diatom concentration (Tables $1 \& 2$ ). At the same food concentration, the maximum and minimum IR was found for Prorocen-

Table 2. Acartia erythraea. Food gut passage time (FPT), ingestion rate (IR), and P assimilation efficiency (AE) in copepods feeding on the diatoms Thalassiosira weissflogii at different concentrations. Data are means $( \pm S D, n=3$ for IR and $\mathrm{AE}$, and $\mathrm{n}=8$ for FPT). Superscripts bearing the same letters in each column mean that no significant difference between the 2 food levels was found

\begin{tabular}{|lccc|}
\hline $\begin{array}{l}\text { Diatom biomass } \\
\left(\mathrm{mg} \mathrm{C}^{-1}\right)\end{array}$ & $\begin{array}{c}\text { FPT } \\
(\mathrm{min})\end{array}$ & $\begin{array}{c}\text { IR }(\mu \mathrm{g} \mathrm{C} \\
\left.\text { copepod }^{-1} \mathrm{~h}^{-1}\right)\end{array}$ & $\begin{array}{c}\text { AE } \\
(\%)\end{array}$ \\
\hline 0.073 & $82 \pm 3^{\mathrm{a}}$ & $0.16 \pm 0.04^{\mathrm{a}}$ & $48.0 \pm 6.4^{\mathrm{a}}$ \\
0.363 & $68 \pm 3^{\mathrm{b}}$ & $0.18 \pm 0.01^{\mathrm{a}}$ & $56.5 \pm 9.0^{\mathrm{a}}$ \\
0.725 & $50 \pm 3^{\mathrm{c}}$ & $0.21 \pm 0.02^{\mathrm{a}}$ & $27.7 \pm 2.9^{\mathrm{b}}$ \\
1.450 & $38 \pm 3^{\mathrm{d}}$ & $0.34 \pm 0.08^{\mathrm{b}}$ & $29.3 \pm 6.9^{\mathrm{b}}$ \\
3.625 & $5 \pm 6^{\mathrm{e}}$ & $0.63 \pm 0.15^{\mathrm{c}}$ & $24.6 \pm 3.2^{\mathrm{b}}$ \\
& & & \\
\hline
\end{tabular}

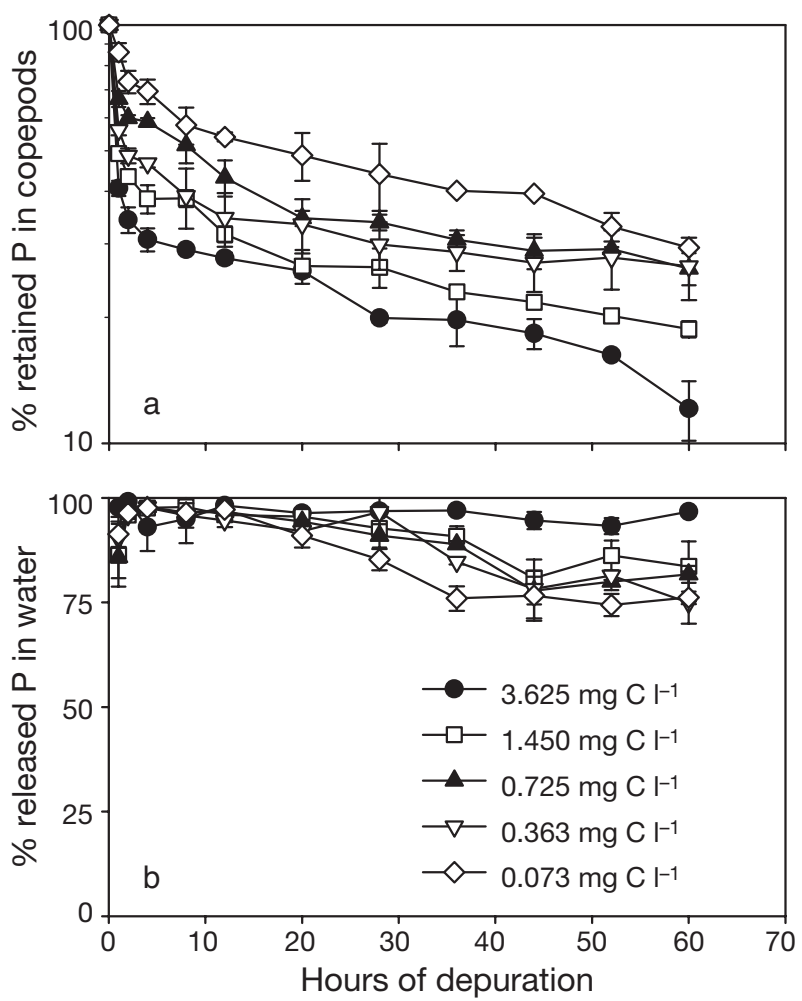

Fig. 4. Acartia erythraea. (a) Retention of dietary ${ }^{33} \mathrm{P}$ in copepods and (b) the relative distribution of eliminated $\mathrm{P}$ in the water following $2 \mathrm{~d}$ of exposure to the radiolabeled diatoms Thalassiosira weissflogii at different concentrations. Data are means $( \pm \mathrm{SD}, \mathrm{n}=3)$ trum minimum $\left(1.33 \mu \mathrm{g} \mathrm{C}\right.$ copepod $\left.^{-1} \mathrm{~h}^{-1}\right)$ and Phaeodactylum tricornutum (0.21 $\mu \mathrm{g}$ C copepod $\left.^{-1} \mathrm{~h}^{-1}\right)$, respectively. The FPT was also dependent on the food species and concentration. In general, the FPT decreased with cell size and cell density. At the same food concentration (1.45 $\mathrm{mg} \mathrm{C}^{-1}$ ), FPT was the shortest when the copepods were fed P. minimum (37 min) and the longest for Dunaliella tertiolecta (57 min). By considering all 6 diets together, there was no significant correlation between the P AE and the IR of copepods, the FPT, or the $\mathrm{P}$ partitioning in the algal cytoplasm. In the diatom concentration experiments, the $P$ AE initially decreased with an increase in IR, but it was then maintained comparably when the IR exceeded $0.21 \mu \mathrm{g} \mathrm{C}$ copepod $^{-1} \mathrm{~h}^{-1}$ (at $0.725 \mathrm{mg} \mathrm{C}^{-1}$ ). No significant relationship between $\mathrm{P}$ AE and FPT was documented in the food concentration experiments.

After 2 wk of semi-continuous culture at different $\mathrm{P}$ concentrations, the $\mathrm{P}$ content in the diatom Thalassiosira weissflogii was $0.9 \pm 0.0,1.6 \pm 0.3$, and $1.7 \pm 0.2 \mathrm{pg} \mathrm{cell}^{-1}$ for $0.7,7.2$, and $36.2 \mu \mathrm{M}$, respectively. When the copepods were fed these diets, the depuration of ingested $P$ was comparable, regardless of the status of $\mathrm{P}$ in the diatoms (Fig. 3). After $12 \mathrm{~h}$ of depuration, ca. $20 \%$ of P was retained in the copepods among the $4 \mathrm{P}$ treatments. The $\mathrm{P}$ AE was $25.5 \pm 2.4,29.0 \pm 1.1$, and $25.4 \pm 6.1 \%$ for 0.7 , 7.2 , and $36.2 \mu \mathrm{MP}$ treatments, respectively, and was independent of the $\mathrm{P}$ quotas in the diatoms. In this experiment, $<40 \%$ of depurated $\mathrm{P}$ was found in the dissolved phase within the first hour of depuration, but this fraction then dominated the depurated $\mathrm{P}$ after $4 \mathrm{~h}$.

\section{Phosphorus efflux}

The P efflux rates by Acartia erythraea were quantified during $60 \mathrm{~h}$ of depuration after copepods ingested the radiolabeled diatoms for $2 \mathrm{~d}$ (Fig. 4); depuration

Table 3. Acartia erythraea. Phosphorus efflux rate constants $\left(k_{\mathrm{e}}\right)$ in copepods feeding on the diatoms Thalassiosira weissflogii at different food concentrations and P additions. Data are means $( \pm S D, n=3)$. Superscripts bearing the same letters mean that no significant difference was found

\begin{tabular}{|lcc|}
\hline & $k_{\mathrm{e}}\left(\mathrm{d}^{-1}\right)$ & $\mathrm{r}^{2}$ \\
\hline Diatom biomass $\left(\mathbf{m g ~ C ~}^{\mathbf{- 1}}\right)$ & & \\
0.073 & $0.32 \pm 0.03$ & 0.89 \\
0.363 & $0.30 \pm 0.03$ & 0.84 \\
0.725 & $0.31 \pm 0.06$ & 0.84 \\
1.450 & $0.31 \pm 0.00$ & 0.92 \\
3.625 & $0.36 \pm 0.04$ & 0.94 \\
$\mathbf{P ~ c o n c e n t r a t i o n ~}(\mathbf{\mu M})$ & & \\
0.7 & $0.33 \pm 0.01^{\mathrm{a}}$ & 0.92 \\
7.2 & $0.48 \pm 0.08^{\mathrm{b}}$ & 0.94 \\
36.2 & $0.46 \pm 0.01^{\mathrm{b}}$ & 0.96 \\
\hline
\end{tabular}




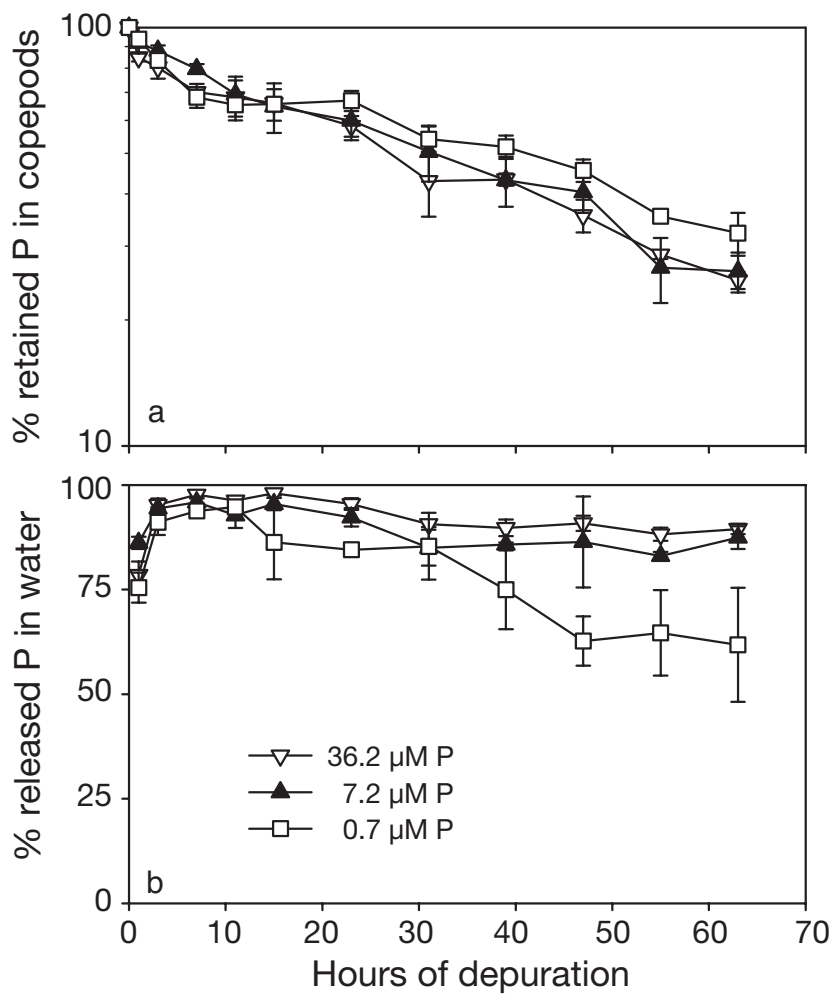

Fig. 5. Acartia erythraea. (a) Retention of dietary ${ }^{33} \mathrm{P}$ in copepods and (b) the relative distribution of eliminated $\mathrm{P}$ in the water following $2 \mathrm{~d}$ of exposure to the radiolabeled diatoms Thalassiosira weissflogii inoculated at different $\mathrm{P}$ concentrations. Data are means $( \pm \mathrm{SD}, \mathrm{n}=3)$

was characterized by rapid loss within the first $4 \mathrm{~h}$, followed by a slower loss afterwards. Depuration between 4 and $60 \mathrm{~h}$ was thus used to calculate the $\mathrm{P}$ efflux rate by the copepods, which was 0.30 to $0.36 \mathrm{~d}^{-1}$ for the different diatom concentration treatments (Table 3). Statistical analysis indicated that the food concentration did not significantly affect the efflux rate of $\mathrm{P}$ in the copepods (ANOVA). During the efflux period, most released $\mathrm{P}$ was regenerated by the copepods into the dissolved phase and there was only a small fraction of $\mathrm{P}$ found in the fecal materials (Fig. 4). No major differences in the relative partitioning were observed among the different food concentration treatments during the initial period of efflux, but later the copepods released a larger fraction of $\mathrm{P}$ into the dissolved phase at a higher food concentration.

The depuration of assimilated P by copepods fed on diatoms inoculated at different $\mathrm{P}$ concentrations is shown in Fig. 5. The efflux rate constant (calculated between 4 and $63 \mathrm{~h}$ of depuration) was $0.33,0.48$, and $0.46 \mathrm{~d}^{-1}$ for diatoms inoculated at $0.7,7.2$, and $36.2 \mu \mathrm{M}$ $\mathrm{P}$, respectively (Table 3 ). Thus, the copepods depurated $\mathrm{P}$ at a lower rate when they ingested the diatoms containing lower $\mathrm{P}$ concentrations, but no significant difference was found between the 7.2 and $36.2 \mu \mathrm{M} P$ treatments. In this experiment, regeneration into the dissolved phase was the dominant route of $P$ efflux. However, the relative partitioning into the dissolved phase decreased for the lowest $\mathrm{P}$ concentration treatment after $30 \mathrm{~h}$ of depuration.

\section{Copepod uptake of regenerated $P$}

During the depuration period, regenerated P may be recycled by the copepods by either direct uptake of dissolved $\mathrm{P}$ or ingestion of algae that may absorb the dissolved $\mathrm{P}$ rapidly. To test such a possibility, we exposed the copepods to the regenerated $\mathrm{P}$ with and without the presence of algae under the same conditions as those used for the $\mathrm{AE}$ and efflux experiments. Direct uptake of dissolved (regenerated) P by the copepods was rather slow, representing up to $1.2 \%$ of the total dissolved $\mathrm{P}$ pool during the $6 \mathrm{~h}$ of exposure (Fig. 6). In the presence of diatoms (grown at 7.2 $\mu \mathrm{MP}$ ), ca. $3 \%$ of the regenerated $\mathrm{P}$ was accumulated by copepods (as a result of ingestion of diatoms and direct uptake of dissolved P) at the 2 high cell densities (1.45 and $3.625 \mathrm{mg} \mathrm{C} \mathrm{l}^{-1}$ ) (Fig. 6). At the low cell density $\left(0.073 \mathrm{mg} \mathrm{Cl}^{-1}\right),<10 \%$ of the regenerated $\mathrm{P}$ was taken up by copepods. Results obtained for diatoms grown at $36.2 \mu \mathrm{M}$ and $\mathrm{P}$ starvation were comparable to those obtained at $7.2 \mu \mathrm{M}$, suggesting that differences in the $P$ status of diatoms did not affect the recycling of

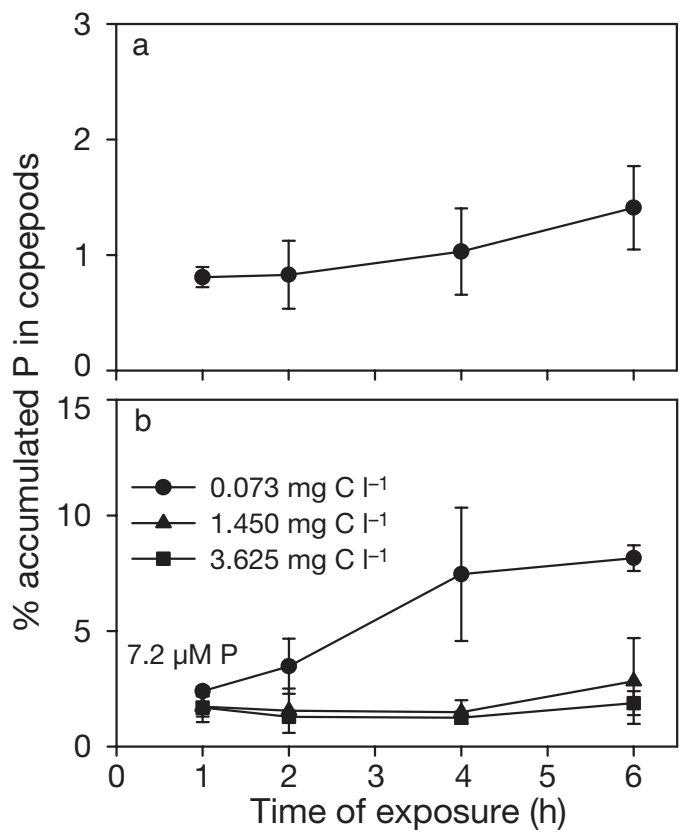

Fig. 6. Acartia erythraea. Percentages of regenerated P accumulated by the copepods (a) without and (b) with the presence of the diatoms Thalassiosira weissflogii at different concentrations. Diatoms were previously grown at 7.2 $\mu \mathrm{M}$ P. Data are means $( \pm \mathrm{SD}, \mathrm{n}=3)$ 
regenerated P by the copepods (data not shown). Overall, these data implied that the recycling of regenerated $\mathrm{P}$ by copepods during the depuration period was negligible.

\section{DISCUSSION}

\section{Phosphorus assimilation}

Zooplankton may play an important role in the biogeochemical cycling of $\mathrm{P}$ in marine environments; they can assimilate dietary $\mathrm{P}$ and regenerate it into the dissolved phase, which may be rapidly recycled by bacterial communities or phytoplankton. Although AE is an important parameter in evaluating the elemental biogeochemical cycle, only a few earlier studies have reported the $\mathrm{P}$ AE in marine copepods, and the results varied. Bulter et al. (1970) noted that only $17 \%$ of algal $\mathrm{P}$ was assimilated by the copepod Calanus finmarchicus, whereas Corner et al. (1972) reported that the P AEs of Calanus sp. ranged between 40 and $77 \%$. Reinfelder \& Fisher (1991) found that the P AE in the copepod Acartia tonsa was ca. $72 \%$. Our measured P AEs were similar to those measured by Corner et al. (1972) and Reinfelder \& Fisher (1991). Clearly, a high proportion of the $\mathrm{P}$ was digested from the food and absorbed across the gut wall. The assimilated P may have subsequently been incorporated into organic molecules and used energetically by the animals (e.g. ATP). Earlier studies reported that only the element in the algal cytoplasm was assimilated by copepods (Reinfelder \& Fisher 1991). Therefore, different algae may influence the $\mathrm{P} A E$ and its fate in aquatic environments, due to their different distributions in the algal cytoplasm. However, there has been only 1 measurement of $\mathrm{P}$ in regard to its distribution in diatoms and its AE by copepods (Reinfelder \& Fisher 1991). Our study, using 6 species of algal diets, did not find a significant relationship between the P AE and the P distribution in the algal cytoplasm, but the percentage assimilated by the copepods was generally much smaller than the percentage of $\mathrm{P}$ partitioning in the algal cytoplasm. Several studies also reported that element assimilation by copepods was affected by both the quantity and quality of food (Xu \& Wang 2001, 2003).

The IR of Acartia erythraea generally increased with increasing food concentration (until the saturation concentration was reached), and it was rather variable among different diets, consistent with earlier studies (Liu \& Wang 2002, Xu \& Wang 2003). Intuitively, one would expect that the P AE would be negatively related to the IR of the copepods, as observed in our diatom food concentration experiment. One possible mechanism underlying the lower P AE with increasing food concentration or IR was the decreasing FPT, which may lead to less efficient digestion and assimilation within the copepod's gut. In contrast, the P assimilation was not related to the IR of A. erythraea or FPT when feeding on different algal diets. It is interesting to note that the copepods had the highest IR and AE on the dinoflagellates Prorocentrum minimum, which were accompanied by the shortest FPT.

When the copepods were fed diatoms with different $\mathrm{P}$ quotas, the P AEs remained rather comparable. Earlier studies demonstrated that marine copepods had low P content, i.e. ca. $0.76 \%$ of their tissue dry weights (Andersen \& Hessen 1991, Walve \& Larsson 1999). In our study, although the algae were grown at different $\mathrm{P}$ concentrations, their $\mathrm{P}$ contents might still have been higher than the requirement by copepods, so there were no significant differences in P AEs among the different $\mathrm{P}$ treatments. The $\mathrm{P}$ contents of the diatoms were reduced ca. 2-fold when grown under P-limited conditions $(0.7 \mu \mathrm{M})$, compared to cells grown under P-enriched conditions ( 7.2 to $36.2 \mu \mathrm{M})$.

Regeneration of $\mathrm{P}$ into the dissolved phase was the predominant route by which the copepods released unassimilated $\mathrm{P}$. The fraction of $\mathrm{P}$ in the dissolved phase increased during the course of depuration. Several recent studies have shown that regeneration into the dissolved phase played a critical role in the elimination of carbon (Xu \& Wang 2003) and metals (Hutchins et al. 1995, Wang \& Fisher 1998, Xu \& Wang 2001) in marine copepods. Thus, by efficiently regenerating particulate $\mathrm{P}$ (from prey) into the dissolved phase, grazing may increase the $P$ residence time and its recycling in surface waters. Furthermore, a low P concentration may support high primary productivity in some coastal ecosystems as a result of the very efficient regeneration of particulate $P$ (Zhang et al. 2004). The very efficient dietary assimilation coupled with the rapid efflux into the dissolved phase suggest that copepods should play a major role in the P food chain dynamics in marine ecosystems.

\section{Phosphorus efflux}

Zooplankton excretion is an important pathway to regenerate elements such as $\mathrm{N}$ and $\mathrm{P}$ (Butler et al. 1970, Landry 1993, Wen \& Peters 1994) and metals (Wang et al. 1996, Wang \& Fisher 1998, Xu \& Wang 2001) in ambient environments. The efflux rate constant is a key parameter to evaluate the physiological turnover of marine zooplankton. Despite the longstanding interest in $\mathrm{P}$ functions and zooplankton activity in aquatic ecosystems, relatively few studies have considered $\mathrm{P}$ turnover in zooplankton. In previous studies, the daily turnover rate of $\mathrm{P}$ was found to be ca. 
$10 \%$ in Calanus finmarchicus (Conover 1961) and $41 \%$ in C. helgolandicus (Corner et al. 1972). Our study presented the first quantitative measurements of the $\mathrm{P}$ efflux rate for a marine copepod. Compared to the excretion rates of biologically essential metals, such as Se $\left(0.16\right.$ to $\left.0.19 \mathrm{~d}^{-1}\right)$ and $\mathrm{Zn}\left(0.05\right.$ to $\left.0.09 \mathrm{~d}^{-1}\right)$ (in the copepod Temora longicornis, Wang \& Fisher 1998), or $\mathrm{N}$ (0.05 to $0.21 \mathrm{~d}^{-1}$ in Acartia spp., Checkley et al. 1992; 0.06 to $0.25 \mathrm{~d}^{-1}$ in A. tonsa, Kiørboe et al. 1985), the $\mathrm{P}$ efflux rates in $A$. erythraea were rather high ( 0.30 to $0.36 \mathrm{~d}^{-1}$ ). However, these rates were very close to the efflux rates of other metals such as $\mathrm{Cd}\left(0.16\right.$ to $\left.0.38 \mathrm{~d}^{-1}\right)$, Ag $\left(0.16\right.$ to $\left.0.29 \mathrm{~d}^{-1}\right)$, and Co $\left(0.22\right.$ to $\left.0.31 \mathrm{~d}^{-1}\right)$ quantified in T. longicornis (Wang \& Fisher 1998) and to carbon measured in Acartia spinicauda (0.13 to $0.37 \mathrm{~d}^{-1}$ ) (Xu \& Wang 2003). Overall, our data indicated that $P$ excretion was an important metabolic route for the marine copepods. The high efflux may result from the rapid turnover of the incorporated $\mathrm{P}$ from metabolic pools (e.g. ATP). In addition, the relatively faster loss of $\mathrm{P}$ from the copepods during the first few hours of the experiments may have been associated with the increased metabolic stress due to crowding of handling. It would be interesting to further examine the metabolically control of P efflux in marine copepods.

Earlier studies found that the element metabolism of zooplankton could be affected by both the quantity and quality of food (Sterner 1990, Hessen \& Andersen 1992, Urabe 1993). Our studies demonstrated that $P$ turnover in Acartia erythraea was rather comparable regardless of the food concentrations. This result is analogous to $\mathrm{N}$ excretion in Calanus pacificus (Miller \& Landry 1984), C excretion in Acartia spinicauda (Xu \& Wang 2003), and Se and Zn excretion in Temora longicornis (Wang \& Fisher 1998). However, the excretion rate of metal $(\mathrm{Cd}, \mathrm{Ag}, \mathrm{Co})$ increased significantly with increasing food concentration (Wang \& Fisher 1998). Therefore, the role of zooplankton in the cycling of elements may be specific for each element according to food conditions and nutritional demands. Olsen \& Østgaard (1985) also reported that the physiological state of algae could affect $P$ turnover.

Wen \& Peters (1994) reported that the excretion rate of P by the freshwater cladoceran Daphnia magna was significantly related to the $\mathrm{N}$ status. Our study also implied that there was an inherent relationship between $\mathrm{P}$ turnover in marine copepods and $\mathrm{P}$ status in the algal diet. Under a sufficient food supply, the P turnover generally increased with increasing P status. Similarly, the release rate of $\mathrm{P}$ by $D$. magna increased with increasing P/C ratio in food (Olsen et al. 1986). Earlier studies indicated that marine copepods have a relatively steady elemental composition (Andersen \& Hessen 1991), and certain species of zooplankton assimilated $\mathrm{C}, \mathrm{N}$, and $\mathrm{P}$ at a relatively stable ratio
(Olsen et al. 1986, Sterner 1989, Hessen 1990). It is possible that the copepods maintained their relatively constant $\mathrm{P}$ contents by modifying the efflux rate of $\mathrm{P}$ from their bodies. Further studies are necessary to examine $\mathrm{P}$ turnover in copepods with different $\mathrm{P}$ body contents.

Our study demonstrated that copepods assimilated ca. 19 to $78 \%$ dietary $\mathrm{P}$ for their growth and productivity, while at the same time they released predominantly unassimilated P into the dissolved pool, with only a small proportion as fecal pellets. The high $\mathrm{P}$ AE and rapid $\mathrm{P}$ efflux were consistent if much of the $\mathrm{P}$ moved through ATP, the molecular most intimately associated with energy transfer pathways. Given the rapid physiological turnover, the copepod's grazing plays an important role in regenerating $P$ to the dissolved pools (Pomeroy et al. 1963), and might make an important contribution to the high primary production in some marine environments with low dissolved $\mathrm{P}$ concentration (Zhang et al. 2004). Copepods had high grazing pressure on phytoplankton. Such high ingestion activity could evidently affect the cycling of $\mathrm{P}$ in surface waters. Furthermore, the homeostasis of $\mathrm{P}$ in copepods may be achieved by modifying their dietary $\mathrm{AE}$ as well as the efflux rate, depending on the different food environments encountered by the copepods (e.g. food concentrations and P quotas in the food).

Acknowledgements. We thank Prof. Michael Landry and the anonymous reviewers for their comments on this work. This study was supported by the Natural Science Foundation of China (No. 40229008 and 40206016).

\section{LITERATURE CITED}

Andersen T, Hessen DO (1991) Carbon, nitrogen, and phosphorus content of freshwater zooplankton. Limnol Oceanogr 36:807-814

Butler EI, Corner ED, Marshall SM (1970) On the nutrition and metabolism of zooplankton. VII. Seasonal survey of nitrogen and phosphorus excretion by Calanus in the Clyde Sea area. J Mar Biol Assoc UK 50:525-560

Checkley DMJ, Dagg MJ, Uye SI (1992) Feeding, excretion and egg production by individuals and populations of the marine, planktonic copepods, Acartia spp. and Centropages furcartus. J Plankton Res 14:71-96

Conover RJ (1961) The turnover of phosphorus by Calanus finmarchicus. J Mar Biol Assoc UK 41:484-488

Corner EDS, Head RN, Kilvington CC (1972) On the nutrition and metabolism of zooplankton. VIII. The grazing of Biddulphia cells by Calanus helgolandicus. J Mar Biol Assoc UK 52:847-861

Hargrave BT, Geen GH (1968) Phosphorus excretion by zooplankton. Limnol Oceanogr 13:332-343

Hessen DO (1990) Carbon, nitrogen, and phosphorus status of Daphnia magna at varying food conditions. J Plankton Res 12:1239-1249

Hessen DO, Andersen T (1992) The algae-grazer interface: feedback mechanisms linked to elemental ratios and nutrient cycling. Ergeb Limnol 35:111-120 
House WA (2003) Geochemical cycling of phosphorus in rivers. Appl Geochem 18:739-748

Hutchins DA, Wang WX, Fisher NS (1995) Copepod grazing and the biogeochemical fate of diatom iron. Limnol Oceanogr 40:989-994

James MR, Salonen K (1991) Zooplankton-phytoplankton interactions and their importance in the phosphorus cycle of a polyhumic lake. Arch Hydrobiol 123:37-51

Kiørboe T, Møhlenberg F, Hamburger K (1985) Bioenergetics of the planktonic copepod Acartia tonsa: relation between feeding, egg production and respiration, and composition of specific dynamic action. Mar Ecol Prog Ser 26:85-97

Klausmeier CA, Litchman E, Dayfresne T, Levin SA (2004) Optimal nitrogen-to-phosphorus stoichiometry of phytoplankton. Nature 429:171-174

Landry MR (1993) Predicting excretion rates of microzooplankton from carbon metabolism and elemental ratios. Limnol Oceanogr 38:468-472

Liu S, Wang WX (2002) Feeding and reproductive responses of marine copepods in South China Sea to toxic and nontoxic phytoplankton. Mar Biol 140:595-603

Marshall SM, Orr AP (1961) On the biology of Calanus finmarchicus. XII. The phosphorus cycle: excretion, egg production, autolysis. J Mar Biol Assoc UK 41:463-483

Miao AJ, Hutchins DA, Yin K, Fu FX, Harrison PJ, Wang WX (2006) Macronutrient and iron limitations of phytoplankton growth in Hong Kong coastal waters. Mar Ecol Prog Ser 318:141-152

Miller CA, Landry MR (1984) Ingestion-independent rates of ammonium excretion by the copepod Calanus pacificus. Mar Biol 78:265-270

Olsen Y, Østgaard K (1985) Estimating release rates of phosphorus from zooplankton, model and experimental verification. Limnol Oceanogr 30:844-852

Olsen Y, Jensen A, Reinertsen H (1986) Dependence of the rate of release of phosphorus by zooplankton on the P:C ratio in the food supply, as calculated by a recycling model. Limnol Oceanogr 31:34-44

Omori M, Ikeda I (1992) Methods in marine zooplankton ecology, 2nd edn. Krieger Press, Malabar, FL

Paytan A, Cade-Menun BJ, McLaughlin K, Faul KL (2003) Selective phosphorus regeneration of sinking marine particles: evidence from ${ }^{31} \mathrm{P}-\mathrm{NMR}$. Mar Chem 82:55-70

Perry MJ, Eppley RW (1981) Phosphate uptake by phytoplankton in the central North Pacific Ocean. Deep-Sea Res Part A 28:39-49

Pomeroy LR, Mathews HM, Min HS (1963) Excretion of phosphate and soluble organic phosphorus compounds by zooplankton. Limnol Oceanogr 8:50-55

Redfield AC (1958) The biological control of chemical factors in the environment. Am Sci 46:205-221

Reinfelder JR, Fisher NS (1991) The assimilation of elements ingested by marine copepods. Science 251:794-796

Editorial responsibility: Otto Kinne (Editor-in-Chief), Oldendorf/Luhe, Germany
Sterner RW (1989) The role of grazers in phytoplankton succession. In: Sommer U (ed) Plankton ecology: succession in plankton communities. Springer, Heidelberg, p $107-170$

Sterner RW (1990) N:P resupply by herbivores: zooplankton and the algal competitive arena. Am Nat 136:209-229

Sterner RW, Elser JJ (2002) Ecological stoichiometry: the biology of elements from molecules to the biosphere. Princeton University Press, Princeton, NJ

Tyrrell T (1999) The relative influences of nitrogen and phosphorus on oceanic primary production. Nature 400:525-531

Urabe J (1993) Coupling N to P cycling through grazers' activities: food quality and nutrient release by zooplankton. Ecology 74:2337-2350

Walve J, Larsson U (1999) Carbon, nitrogen and phosphorus stoichiometry of crustacean zooplankton in the Baltic Sea, implications for nutrient recycling. J Plankton Res 21: $2309-2321$

Wang WX (2002) Interaction of trace metal and different marine food chain. Mar Ecol Prog Ser 243:295-309

Wang WX, Fisher NS (1996) Assimilation of trace elements and carbon by the mussel Mytilus edulis: effects of food composition. Limnol Oceanogr 41:197-207

Wang WX, Fisher NS (1998) Accumulation of trace elements in a marine copepod. Limnol Oceanogr 43:273-283

Wang WX, Fisher NS (1999) Assimilation efficiencies of chemical contaminants in aquatic invertebrates: a synthesis. Environ Toxicol Chem 18:2034-2045

Wang WX, Reinfelder JR, Lee BG, Fisher NS (1996) Assimilation and regeneration of trace elements by marine copepods. Limnol Oceanogr 41:70-81

Wen YH, Peters RH (1994) Empirical models of phosphorus and nitrogen excretion rates by zooplankton. Limnol Oceanogr 39:1669-1679

Xu Y, Wang WX (2001) Individual responses of trace element assimilation and physiological turnover by marine copepod Calanus sinicus to changes in food quantity. Mar Ecol Prog Ser 218:227-238

Xu Y, Wang WX (2003) Fates of diatom carbon and trace elements by the grazing of a marine copepod. Mar Ecol Prog Ser 254:225-238

Yin K, Qian PY, Chen JC, Hsieh DPH, Harrison PJ (2000) Dynamics of nutrients and phytoplankton biomass in the Pearl River estuary and adjacent waters of Hong Kong during summer: preliminary evidence for phosphorus and silicon limitation. Mar Ecol Prog Ser 194:295-305

Zhang J, Yu ZG, Wang JT, Ren JL, Chen HT, Xiong H, Dong LX, Xu WY (1999) The subtropical Zhujiang (Pearl River) Estuary: nutrient, trace species and their relationship to photosynthesis. Estuar Coast Shelf Sci 49:385-400

Zhang Y, Zhu L, Zeng X, Lin Y (2004) The biogeochemical cycling of phosphorus in the upper ocean of the East China Sea. Estuar Coast Shelf Sci 60:369-379

Submitted: November 24, 2005; Accepted: February 27, 2006 Proofs received from author(s): August 14, 2006 